\title{
Optimasi Konsentrasi Etanol Dan Perbandingan Bahan Dengan Etanol Terhadap Aktivitas Antioksidan Ekstrak Daun Beluntas (Pluchea Indica Less) Menggunakan Response Surface Methodology (RSM)
}

\section{Optimization of Ethanol Concentration and Comparison of Material with Ethanol on Antioxidant Activity of Beluntas Leaves Extract (Pluchea indica Less) Using Response Surface Methodology (RSM)}

\section{Gusti Ngurah Bagus Pranantha Bistara Kusuma ${ }^{1}$, I Ketut Suter ${ }^{1 *}$, Gusti Ayu Kadek Diah Puspawati ${ }^{1}$}

\author{
Program Studi Teknologi Pangan, Fakultas Teknologi Pertanian, Universitas Udayana \\ Kampus Bukit Jimbaran, Badung-Bali \\ *Penulis korespondensi: I Ketut Suter, Email: suter@unud.ac.id
}

\begin{abstract}
The research was conducted to obtain the optimum of ethanol concentration and comparison of material with ethanol to produced beluntas leaves extract that had the highest antioxidant activiy. Response Surface Methodology (RSM) was used for optimization of extraction conditions with experimental design was a Central Composite Design (CCD) in two factors, namely ethanol concentration and comparison of material with ethanol. The results showed that the optimum conditions of beluntas leaves extraction were at ethanol concentration $62.71 \%$ and the comparison of material with ethanol 1:10.14. In this condition, the highest antioxidant activity was obtained at $65.80 \%$ with $\mathrm{IC}_{50}$, extract yield, total flavonoid content, and total tannin content were $3.87 \mathrm{ppm}, 18.20 \%$ dry weight extract, $47.05 \mathrm{mg}$ QE/g dry weight extract, and 9.11 $\mathrm{mg}$ TAE/g dry weight extract, respectively.
\end{abstract}

Keywords: extraction, antioxidant activity, beluntas leaves, response surface methodology

\section{PENDAHULUAN}

Tanaman beluntas (Pluchea indica Less) merupakan salah satu tanaman dari family Asteraceae yang dapat tumbuh di daerah kering pada tanah keras dan berbatu. Tanaman ini sejak dahulu telah dimanfaatkan oleh masyarakat sebagai salah satu obat-obatan tradisional, baik dikonsumsi dalam bentuk lalapan atau dengan meminum air rebusan daun beluntas. Daun beluntas mengandung komponen bioaktif, yaitu alkaloid, tanin, dan flavonoid serta dimanfaatkan oleh masyarakat sebagai obat alternatif untuk menghilangkan bau badan, menghilangkan bau mulut, dan menurunkan demam (Dalimartha, 1999). Hassig et al., (1999) melaporkan bahwa flavonoid dan tanin memiliki fungsi sebagai antioksidan karena dapat mengikat radikal bebas dengan melengkapi kekurangan elektron pada radikal bebas. Pengambilan flavonoid dan tanin dari suatu tanaman dapat dilakukan dengan ekstraksi. Ekstraksi dapat dilakukan dengan beberapa metode, salah satunya yaitu metode Microwave Assisted Extraction (MAE) dengan memanfaatkan radiasi gelombang mikro (Jain et al., 2009).

Faktor-faktor yang mempengaruhi laju ekstraksi adalah konsentrasi pelarut dan perbandingan bahan dengan pelarut. 
Konsentrasi pelarut berpengaruh terhadap laju ekstraksi karena terdapat perbedaan polaritas dari masing-masing konsentrasi pelarut yang dapat mempengaruhi kelarutan komponen bioaktif dalam pelarut (Tan et al., 2013). Perbandingan bahan dengan pelarut juga berpengaruh terhadap laju ekstraksi karena semakin besar volume pelarut yang digunakan, maka kemampuan pelarut untuk melarutkan bahan akan semakin tinggi, sehingga komponen bahan yang terekstrak ke dalam pelarut akan semakin banyak (Handayani et al., 2016).

Nilai aktivitas antioksidan akan meningkat hingga konsentrasi pelarut dan perbandingan bahan dengan pelarut pada titik optimum, namun setelah mencapai titik optimum, nilai aktivitas antioksidan akan menurun dengan peningkatan konsentrasi pelarut dan perbandingan bahan dengan pelarut. Pernyataan tersebut diperkuat oleh penelitian Alara et al., (2018) yang melaporkan bahwa terjadi peningkatan nilai aktivitas antioksidan pada ekstrak daun afrika hingga konsentrasi etanol dan perbandingan bahan dengan etanol pada titik optimum, namun setelah mencapai titik optimum, terjadi penurunan nilai aktivitas antioksidan dengan peningkatan konsentrasi etanol dan perbandingan bahan dengan etanol.

Berdasarkan latar belakang tersebut, maka perlu dilakukan penelitian tentang optimasi konsentrasi etanol dan perbandingan bahan dengan etanol menggunakan response surface methodology (RSM). RSM adalah gabungan teknik statistik dan matematika yang digunakan untuk mengetahui kondisi optimum dari suatu variabel bebas yang mempengaruhi suatu respon dan untuk mengoptimalkan respon (Box et al., 1978). Keuntungan dari RSM adalah berkurangnya jumlah unit percobaan yang dibutuhkan untuk memperoleh hasil yang secara statistik dapat diterima, sehingga tidak membutuhkan waktu yang lama dan dapat menghemat biaya (Iriawan dan Astuti, 2006). Penggunaan metode RSM untuk optimasi proses ekstraksi telah dilakukan oleh Alara et al., (2018) pada ekstraksi daun afrika, Radojkovic et al., (2012a) pada ekstraksi daun murbei, dan Radojkovic et al., (2012b) pada ekstraksi daun murbei hitam. Dalam penelitian ini, RSM digunakan untuk mendapatkan konsentrasi etanol dan perbandingan bahan dengan etanol yang optimum untuk menghasilkan ekstrak daun beluntas yang memiliki aktivitas antioksidan tertinggi.

\section{METODE PENELITIAN}

\section{Tempat dan Waktu}

Penelitian ini dilaksanakan di Laboratorium Analisis Pangan, Laboratorium Pengolahan Pangan, serta Laboratorium Rekayasa Proses dan Pengendalian Mutu, Program Studi Ilmu dan Teknologi Pangan, Fakultas Teknologi Pertanian, Universitas Udayana. Penelitian 
ini dilaksanakan pada bulan November 2019 sampai dengan bulan Januari 2020.

\section{Bahan dan Alat}

Bahan-bahan yang digunakan dalam penelitian ini, yaitu daun beluntas dengan karakteristik daun yang digunakan, yaitu ruas daun nomor 1 sampai 3 dari pucuk daun, yang diperoleh di Desa Gulingan, Kecamatan Mengwi, Kabupaten Badung, etanol p.a (Merck), DPPH (Himedia), aquades, reagen Folin-Denis (Merck), larutan $\mathrm{Na}_{2} \mathrm{CO}_{3}$ (Merck), larutan $\mathrm{NaNO}_{2}$ (Merck), larutan $\mathrm{AlCl}_{3}$ (Merck), larutan $\mathrm{NaOH}$ (Merck), standar kuersetin (Sigma Aldrich), dan standar asam tanat (Merck).

Alat-alat yang digunakan dalam penelitian ini, yaitu microwave oven (Samsung), spektrofotometer (Genesys $10 S$ UV-Vis), rotary evaporator (IKA Labortechnik), software Minitab 17, ayakan 60 mesh (Retsch), timbangan analitik (Shimadzu ATY224), oven (Blue M), loyang, vortex (Maxi Mix II Type 367000), centrifuge (Damon/IEC Division), pipet mikro (Accumax PRO), tip, cawan aluminium, desikator, pinset, pipet tetes, pipet volume (Iwaki), bola hisap $(D \& N)$, kertas whatman no. 1, corong, aluminium foil, spatula, gelas beker (Pyrex), gelas ukur (Herma), labu ukur (Iwaki), tabung reaksi (Pyrex), botol kaca berwarna gelap, dan blender (Miyako).

\section{Rancangan Penelitian}

Penelitian ini menggunakan Central Composite Design (CCD) dalam dua faktor, yaitu konsentrasi etanol dan perbandingan bahan dengan etanol. Response Surface Methodology (RSM) digunakan untuk mengetahui kondisi optimum dari variabel bebas (X) yaitu konsentrasi etanol dan perbandingan bahan dengan etanol terhadap respon (Y) yaitu rendemen ekstrak, total flavonoid, total tanin, aktivitas antioksidan, dan $\mathrm{IC}_{50}$. Variabel bebas, kode, dan nilai yang dioptimasi dapat dilihat pada Tabel 1 serta kombinasi perlakuan konsentrasi etanol dan perbandingan bahan dengan etanol yang dioptimasi dapat dilihat pada Tabel 2.

Tabel 1. Level variabel bebas, kode, dan nilai yang dioptimasi

\begin{tabular}{cccccc}
\hline Variabel Bebas & $-1,414$ & -1 & 0 & +1 & $+1,414$ \\
\cline { 2 - 6 } & 45,86 & 50 & 60 & 70 & 74,14 \\
\hline Konsentrasi Etanol, $\mathrm{X}_{1}(\%)$ & $1: 8$ & $1: 10$ & $1: 12$ & $1: 12,83$ \\
Perbandingan Bahan & $1: 7,17$ & & & & \\
dengan Etanol, $\mathrm{X}_{2}(\mathrm{~b} / \mathrm{v})$ & & &
\end{tabular}


Tabel 2. Kombinasi perlakuan konsentrasi etanol dan perbandingan bahan dengan etanol yang dioptimasi

\begin{tabular}{ccccc}
\hline No. & $\begin{array}{c}\text { Variasi Kode } \\
\mathrm{X}_{1}\end{array}$ & $\begin{array}{c}\text { Variasi } \\
\text { Perlakuan } \\
\mathrm{X}_{2}\end{array}$ & $\begin{array}{c}\text { Konsentrasi Etanol } \\
(\%)\end{array}$ & $\begin{array}{c}\text { Perbandingan Bahan } \\
\text { dengan Etanol }(\mathrm{b} / \mathrm{v})\end{array}$ \\
\hline 1. & -1 & -1 & 50 & $1: 8$ \\
2. & 1 & -1 & 70 & $1: 8$ \\
3. & -1 & 1 & 50 & $1: 12$ \\
4. & 1 & 1 & 70 & $1: 12$ \\
5. & $-1,414$ & 0 & 45,86 & $1: 10$ \\
6. & 1,414 & 0 & 74,14 & $1: 10$ \\
7. & 0 & $-1,414$ & 60 & $1: 7,17$ \\
8. & 0 & 1,414 & 60 & $1: 10$ \\
9. & 0 & 0 & 60 & $1: 10$ \\
10. & 0 & 0 & 60 & $1: 10$ \\
11. & 0 & 0 & 60 & $1: 10$ \\
12. & 0 & 0 & 60 & $1: 10$ \\
13. & 0 & 0 & 60 & \\
\hline
\end{tabular}

\section{Parameter yang Diamati}

Parameter yang diamati dalam penelitian ini, yaitu rendemen bubuk yang dihitung berdasarkan berat bubuk terhadap daun (AOAC, 1990), rendemen ekstrak yang dihitung berdasarkan berat ekstrak terhadap bubuk (AOAC, 1990), total flavonoid menggunakan metode aluminium klorida (Pujimulyani et al., 2010), total tanin menggunakan metode folin-denis (Rajan et al., 2011), serta aktivitas antioksidan dan $\mathrm{IC}_{50}$ menggunakan metode DPPH (Khan et al., 2012).

\section{Pelaksanaan Penelitian \\ Persiapan Sampel}

Daun beluntas ditimbang sebanyak 2 $\mathrm{kg}$ kemudian dibersihkan dalam air mengalir untuk menghilangkan kotoran yang menempel pada daun lalu ditiriskan untuk menghilangkan air sisa pencucian. Daun beluntas yang sudah bersih kemudian dikeringkan menggunakan oven pada suhu $40^{\circ} \mathrm{C}$ selama $12 \mathrm{jam}$. Daun beluntas kering kemudian dihaluskan menggunakan blender lalu diayak menggunakan ayakan 60 mesh sehingga diperoleh bubuk daun beluntas (Suryani et al., 2016 yang telah dimodifikasi). Bubuk yang diperoleh kemudian ditimbang untuk selanjutnya dilakukan analisis bubuk.

\section{Pembuatan Ekstrak Kasar}

Pembuatan ekstrak kasar diawali dengan penimbangan bubuk daun beluntas masing-masing sebanyak $10 \mathrm{~g}$ yang dilarutkan dalam variasi konsentrasi etanol dan perbandingan bahan dengan etanol sesuai dengan kombinasi perlakuan yang dioptimasi pada Tabel 2. Ekstraksi dilakukan menggunakan microwave oven dengan daya 800 watt selama 6 menit. Setiap 1 menit microwave oven dimatikan lalu didiamkan selama 2 menit dan perlakuan ini diulang sebanyak 2 kali sehingga total waktu 
ekstraksi yang dibutuhkan, yaitu selama 6 menit (Quan et al., 2006), kemudian didiamkan sampai suhu kamar lalu disaring menggunakan kertas whatman no. 1 sehingga menghasilkan filtrat.

Filtrat yang diperoleh kemudian dipekatkan menggunakan rotary evaporator pada suhu $40^{\circ} \mathrm{C}$ dengan kecepatan $55 \mathrm{rpm}$ dalam tekanan 100 mbar sampai seluruh etanol menguap sehingga diperoleh ekstrak kasar daun beluntas (Suryani et al., 2016 yang telah dimodifikasi). Ekstrak kasar yang diperoleh kemudian dimasukkan ke dalam botol kaca berwarna gelap untuk selanjutnya dilakukan analisis rendemen ekstrak, total flavonoid, total tanin, aktivitas antioksidan, dan $\mathrm{IC}_{50}$

\section{Analisis Data}

Analisis data dilakukan dengan bantuan software Minitab 17. Dari analisis ini akan diperoleh model persamaan kuadratik dengan bentuk persamaan sebagai berikut:

$Y=\beta_{0}+\beta_{1} X_{1}+\beta_{2} X_{2}+\beta_{3} X_{1}^{2}+\beta_{4} X_{2}^{2}+$ $\beta_{5} \mathrm{X}_{1} \mathrm{X}_{2}$

Dalam hal ini, Y adalah respon, $\beta_{0}$ adalah konstanta, $\beta_{1}, \beta_{2}, \beta_{3}, \beta_{4}$, dan $\beta_{5}$ adalah koefesien dari variabel bebas (X), $\mathrm{X}$ adalah variabel bebas tanpa kode $\left(\mathrm{X}_{1}\right.$ untuk variabel konsentrasi etanol dan $\mathrm{X}_{2}$ untuk variabel perbandingan bahan dengan etanol). Hasil dari masing-masing respon $(\mathrm{Y})$ dianalisis menggunakan analysis of variance pada software Minitab 17. Model persamaan kuadratik di atas kemudian diuji pengaruh variabel bebas terhadap respon $\left(\mathrm{R}^{2}\right)$ dan ketidakcocokan model persamaan kuadratik (lack of fit) (Montgomery, 2001). Validasi kondisi optimum dilakukan dengan melihat nilai coefficient of variation dari respon pada kondisi optimum (Gomez and Gomez, 1984).

\section{HASIL DAN PEMBAHASAN}

Perbandingan antara berat bubuk daun beluntas dengan berat daun beluntas menunjukkan rendemen bubuk yaitu sebesar $11,81 \%$ berat basah dengan kadar air bubuk sebesar 7,57\%, sedangkan hasil analisis rendemen ekstrak, kadar air ekstrak, total flavonoid, total tanin, aktivitas antioksidan, dan $\mathrm{IC}_{50}$ ekstrak daun beluntas berdasarkan Central Composite Design dapat dilihat pada Tabel 3. Model persamaan kuadratik, nilai $\mathrm{R}^{2}$, dan lack of fit dari masing-masing respon dapat dilihat pada Tabel 4 serta prediksi kondisi optimum dari masingmasing respon berdasarkan central composite design dapat dilihat pada Tabel 5.

Hasil analisis rendemen ekstrak, kadar air ekstrak, total flavonoid, total tanin, aktivitas antioksidan, dan $\mathrm{IC}_{50}$ ekstrak daun beluntas berdasarkan Central Composite Design pada Tabel 3 menunjukkan bahwa ekstrak daun beluntas memiliki rendemen ekstrak berkisar antara 8,68-19,03\% berat kering ekstrak, kadar air ekstrak berkisar antara 22,46-24,44\%, total flavonoid berkisar antara 41,48-47,89 $\mathrm{mg}$ QE/g berat kering ekstrak, total tanin berkisar antara 4,76-9,23 mg TAE/g berat kering ekstrak, 
aktivitas antioksidan berkisar 51,03$75,04 \%$, dan $\mathrm{IC}_{50}$ berkisar 3,41-4,85 ppm.

Model persamaan kuadratik pada Tabel 4 digunakan untuk memprediksi nilai rendemen ekstrak tertinggi, total flavonoid tertinggi, total tanin tertinggi, aktivitas antioksidan tertinggi, dan $\mathrm{IC}_{50}$ terendah pada kondisi optimum. Nilai $\mathrm{R}^{2}$ (koefisien determinasi) pada Tabel 4 menunjukkan seberapa besar pengaruh konsentrasi etanol dan perbandingan bahan dengan etanol terhadap rendemen ekstrak, total flavonoid, total tanin, aktivitas antioksidan, dan $\mathrm{IC}_{50}$ ekstrak daun beluntas.

Tabel 3. Hasil analisis rendemen ekstrak, kadar air ekstrak, total flavonoid, total tanin, aktivitas antioksidan, dan $\mathrm{IC}_{50}$ ekstrak daun beluntas berdasarkan central composite design

\begin{tabular}{cccccccc}
\hline $\begin{array}{c}\text { Konsentrasi } \\
\text { Etanol (\%) }\end{array}$ & $\begin{array}{c}\text { Perbandingan } \\
\text { Bahan dengan } \\
\text { Etanol (b/v) }\end{array}$ & $\begin{array}{c}\text { Rendemen } \\
\text { Ekstrak } \\
(\% \text { berat } \\
\text { kering } \\
\text { ekstrak) }\end{array}$ & $\begin{array}{c}\text { Kadar } \\
\text { Air } \\
\text { Ekstrak } \\
(\%)\end{array}$ & $\begin{array}{c}\text { Total } \\
\text { Flavonoid } \\
\text { (mg QE/g } \\
\text { berat kering } \\
\text { ekstrak) }\end{array}$ & $\begin{array}{c}\text { Total Tanin } \\
\text { (mg TAE/g } \\
\text { berat kering } \\
\text { ekstrak) }\end{array}$ & $\begin{array}{c}\text { Aktivitas } \\
\text { Antioksidan } \\
(\%)\end{array}$ & $\begin{array}{c}\mathrm{IC}_{50} \\
(\mathrm{ppm})\end{array}$ \\
\hline 50 & $1: 8$ & 11,06 & 22,92 & 42,74 & 4,91 & 51,77 & 4,82 \\
70 & $1: 8$ & 13,88 & 23,22 & 43,57 & 6,23 & 53,10 & 4,38 \\
50 & $1: 12$ & 12,62 & 23,05 & 43,09 & 5,70 & 52,06 & 4,63 \\
70 & $1: 12$ & 16,23 & 23,75 & 45,42 & 7,83 & 65,49 & 3,86 \\
45,86 & $1: 10$ & 8,68 & 22,56 & 41,48 & 4,76 & 51,03 & 4,85 \\
74,14 & $1: 10$ & 14,08 & 23,21 & 43,78 & 6,38 & 54,42 & 4,29 \\
60 & $1: 7,17$ & 15,84 & 22,46 & 44,12 & 7,19 & 60,32 & 4,02 \\
60 & $1: 12,83$ & 13,72 & 23,14 & 43,36 & 6,12 & 52,75 & 4,61 \\
60 & $1: 10$ & 16,65 & 23,92 & 45,82 & 7,91 & 67,90 & 3,82 \\
60 & $1: 10$ & 16,17 & 23,70 & 45,35 & 7,67 & 65,08 & 3,89 \\
60 & $1: 10$ & 16,07 & 23,52 & 45,01 & 7,38 & 62,56 & 3,94 \\
60 & $1: 10$ & 19,03 & 24,44 & 47,89 & 9,23 & 75,04 & 3,41 \\
60 & $1: 10$ & 18,04 & 24,19 & 46,76 & 9,00 & 68,05 & 3,78 \\
\hline
\end{tabular}

Tabel 4. Model persamaan kuadratik, nilai $\mathrm{R}^{2}$, dan lack of fit dari masing-masing respon

\begin{tabular}{clcc}
\hline Respon & \multicolumn{1}{c}{ Model Persamaan Kuadratik } & $\mathrm{R}^{2}$ & $\begin{array}{c}\text { Lack of } \\
\text { Fit }\end{array}$ \\
\hline Rendemen Ekstrak & $\mathrm{Y}=-117,2+3,455 \mathrm{X}_{1}+5,03 \mathrm{X}_{2}-0,02816 \mathrm{X}_{1}^{2}-0,279 \mathrm{X}_{2}^{2}+0,0099 \mathrm{X}_{1} \mathrm{X}_{2}$ & $86,52 \%$ & 0,394 \\
Total Flavonoid & $\mathrm{Y}=-34,2+1,858 \mathrm{X}_{1}+4,36 \mathrm{X}_{2}-0,01639 \mathrm{X}_{1}^{2}-0,2713 \mathrm{X}_{2}^{2}+0,0188 \mathrm{X}_{1} \mathrm{X}_{2}$ & $80,34 \%$ & 0,724 \\
Total Tanin & $\mathrm{Y}=-57,4+1,551 \mathrm{X}_{1}+3,33 \mathrm{X}_{2}-0,01319 \mathrm{X}_{1}^{2}-0,1944 \mathrm{X}_{2}^{2}+0,0103 \mathrm{X}_{1} \mathrm{X}_{2}$ & $79,91 \%$ & 0,470 \\
Aktivitas & $\mathrm{Y}=-252+7,44 \mathrm{X}_{1}+17,8 \mathrm{X}_{2}-0,0726 \mathrm{X}_{1}^{2}-1,338 \mathrm{X}_{2}^{2}+0,151 \mathrm{X}_{1} \mathrm{X}_{2}$ & $77,58 \%$ & 0,399 \\
Antioksidan & & & \\
$\mathrm{IC}_{50}$ & $\mathrm{Y}=23,69-0,459 \mathrm{X}_{1}-1,087 \mathrm{X}_{2}+0,00396 \mathrm{X}_{1}^{2}+0,0671 \mathrm{X}_{2}^{2}-0,00413 \mathrm{X}_{1} \mathrm{X}_{2}$ & $79,74 \%$ & 0,205 \\
\hline
\end{tabular}

Nilai lack of fit dari masing-masing respon pada Tabel 4 lebih besar dari 0,05 yang artinya ketidakcocokan model persamaan kuadratik ditolak, sehingga model persamaan kuadratik tersebut dapat digunakan untuk memprediksi nilai rendemen ekstrak tertinggi, total flavonoid tertinggi, total tanin tertinggi, aktivitas antioksidan tertinggi, dan $\mathrm{IC}_{50}$ terendah pada kondisi optimum. 
Tabel 5. Prediksi kondisi optimum dari masing-masing respon berdasarkan central composite design

\begin{tabular}{|c|c|c|c|c|c|c|}
\hline \multirow{2}{*}{ Respon } & \multicolumn{7}{|c|}{ Variabel Bebas } \\
\cline { 2 - 8 } & $\begin{array}{c}\text { Konsentrasi } \\
\text { Etanol (\%) }\end{array}$ & $\begin{array}{c}\text { Perbandingan } \\
\text { Bahan dengan } \\
\text { Etanol (b/v) }\end{array}$ & & & & \\
\cline { 2 - 8 } & Rendah & Tinggi & Optimum & Rendah & Tinggi & Optimum \\
\hline $\begin{array}{c}\text { Rendemen } \\
\text { Ekstrak }\end{array}$ & 45,86 & 74,14 & 63,28 & $1: 7,17$ & $1: 12,83$ & $1: 10,14$ \\
\hline $\begin{array}{c}\text { Total } \\
\text { Flavonoid }\end{array}$ & 45,86 & 74,14 & 62,43 & $1: 7,17$ & $1: 12,83$ & $1: 10,20$ \\
\hline Total Tanin & 45,86 & 74,14 & 62,71 & $1: 7,17$ & $1: 12,83$ & $1: 10,20$ \\
\hline $\begin{array}{c}\text { Aktivitas } \\
\text { Antioksidan }\end{array}$ & 45,86 & 74,14 & 61,86 & $1: 7,17$ & $1: 12,83$ & $1 ; 10,14$ \\
\hline IC 50 & 45,86 & 74,14 & 63,28 & $1: 7,17$ & $1: 12,83$ & $1: 10,03$ \\
\hline
\end{tabular}

\section{Rendemen Ekstrak}

Semakin tinggi konsentrasi etanol dan semakin besar perbandingan bahan dengan etanol, maka nilai rendemen ekstrak akan semakin meningkat, namun setelah mencapai titik optimum pada konsentrasi etanol $63,28 \%$ dan perbandingan bahan dengan etanol $1: 10,14$, nilai rendemen ekstrak menurun dengan peningkatan konsentrasi etanol dan perbandingan bahan dengan etanol.

Peningkatan nilai rendemen ekstrak hingga konsentrasi etanol dan perbandingan bahan dengan etanol yang optimum disebabkan karena adanya peningkatan kesesuaian polaritas antara pelarut dengan senyawa yang diekstrak dan semakin besar luas kontak antara pelarut dengan bahan yang diekstrak. Pernyataan tersebut diperkuat oleh penelitian Jayanudin et al., (2014) yang melaporkan bahwa luas kontak antara pelarut dengan bahan berpengaruh terhadap rendemen ekstrak yang dihasilkan pada ekstrak rumput laut cokelat. Senyawa yang terekstrak akan terus meningkat hingga tercapai kesetimbangan antara konsentrasi senyawa di dalam pelarut dengan konsentrasi senyawa di dalam bahan yang diekstrak (McCabe et al., 1993).

Pada titik optimum, pelarut memiliki polaritas yang sama dengan senyawa yang diekstrak dan jumlah pelarut yang dibutuhkan sudah maksimal untuk kontak dengan bahan yang diekstrak atau mengambil senyawa yang diekstrak hingga tercapai kesetimbangan antara konsentrasi senyawa di dalam pelarut dengan konsentrasi senyawa di dalam bahan yang diekstrak, akibatnya rendemen ekstrak tertinggi dihasilkan pada titik optimum. Pernyataan tersebut diperkuat oleh penelitian Lestari et al., (2014) yang melaporkan bahwa pelarut yang memiliki polaritas yang sama dengan senyawa yang diekstrak akan memberikan hasil yang lebih maksimal.

Setelah mencapai titik optimum, terjadi penurunan nilai rendemen ekstrak 
yang disebabkan karena mulai menurunnya kesesuaian polaritas antara pelarut dengan senyawa yang diekstrak dan jumlah senyawa yang terekstrak ke dalam pelarut sudah berkurang, sehingga rendemen ekstrak yang dihasilkan menurun. Penelitian tentang daun beluntas juga dilakukan oleh Yulianto dan Savitri (2019) yang melaporkan rendemen ekstrak daun beluntas sebesar 13,24\% menggunakan pelarut etanol $50 \%(1: 5 \mathrm{~b} / \mathrm{v})$ dengan metode maserasi.

\section{Total Flavonoid}

Semakin tinggi konsentrasi etanol dan semakin besar perbandingan bahan dengan etanol, maka total flavonoid akan semakin meningkat, namun setelah mencapai titik optimum pada konsentrasi etanol $62,43 \%$ dan perbandingan bahan dengan etanol $1: 10,20$, total flavonoid menurun dengan peningkatan konsentrasi etanol dan perbandingan bahan dengan etanol.

Peningkatan total flavonoid hingga konsentrasi etanol dan perbandingan bahan dengan etanol yang optimum disebabkan karena adanya peningkatan kesesuaian polaritas antara pelarut dengan senyawa yang diekstrak dan semakin besar luas kontak antara pelarut dengan bahan yang diekstrak. Senyawa flavonoid yang terekstrak akan terus meningkat hingga tercapai kesetimbangan antara konsentrasi senyawa di dalam pelarut dengan konsentrasi senyawa di dalam bahan yang diekstrak (McCabe et al., 1993).

Pada titik optimum, pelarut memiliki polaritas yang sama dengan senyawa yang diekstrak dan jumlah pelarut yang dibutuhkan sudah maksimal untuk kontak dengan bahan yang diekstrak atau mengambil senyawa yang diekstrak hingga tercapai kesetimbangan antara konsentrasi senyawa di dalam pelarut dengan konsentrasi senyawa di dalam bahan yang diekstrak, akibatnya total flavonoid tertinggi dihasilkan pada titik optimum. Pernyataan tersebut diperkuat oleh penelitian Lestari et al., (2014) yang melaporkan bahwa pelarut yang memiliki polaritas yang sama dengan senyawa yang diekstrak akan memberikan hasil yang lebih maksimal.

Setelah mencapai titik optimum, terjadi penurunan total flavonoid yang disebabkan karena mulai menurunnya kesesuaian polaritas antara pelarut dengan senyawa yang diekstrak dan jumlah senyawa yang terekstrak ke dalam pelarut sudah berkurang, sehingga total flavonoid yang dihasilkan menurun. Penelitian tentang daun beluntas juga dilakukan oleh Srimoon (2018) yang melaporkan total flavonoid ekstrak daun beluntas sebesar $45,15 \mathrm{mg}$ $\mathrm{QE} / \mathrm{g}$ berat kering menggunakan pelarut etanol $70 \% \quad(1: 5 \quad b / v)$ dengan metode maserasi.

\section{Total Tanin}

Semakin tinggi konsentrasi etanol dan semakin besar perbandingan bahan dengan etanol, maka total tanin akan semakin meningkat, namun setelah mencapai titik optimum pada konsentrasi etanol 62,71\% 
dan perbandingan bahan dengan etanol $1: 10,20$, total tanin menurun dengan peningkatan konsentrasi etanol dan perbandingan bahan dengan etanol.

Peningkatan total tanin hingga konsentrasi etanol dan perbandingan bahan dengan etanol yang optimum disebabkan karena adanya peningkatan kesesuaian polaritas antara pelarut dengan senyawa yang diekstrak dan semakin besar luas kontak antara pelarut dengan bahan yang diekstrak. Senyawa tanin yang terekstrak akan terus meningkat hingga tercapai kesetimbangan antara konsentrasi senyawa di dalam pelarut dengan konsentrasi senyawa di dalam bahan yang diekstrak (McCabe et al., 1993).

Pada titik optimum, pelarut memiliki polaritas yang sama dengan senyawa yang diekstrak dan jumlah pelarut yang dibutuhkan sudah maksimal untuk kontak dengan bahan yang diekstrak atau mengambil senyawa yang diekstrak hingga tercapai kesetimbangan antara konsentrasi senyawa di dalam pelarut dengan konsentrasi senyawa di dalam bahan yang diekstrak, akibatnya total tanin tertinggi dihasilkan pada titik optimum. Pernyataan tersebut diperkuat oleh penelitian Lestari et al., (2014) yang melaporkan bahwa pelarut yang memiliki polaritas yang sama dengan senyawa yang diekstrak akan memberikan hasil yang lebih maksimal.

Setelah mencapai titik optimum, terjadi penurunan total tanin yang disebabkan karena mulai menurunnya kesesuaian polaritas antara pelarut dengan senyawa yang diekstrak dan jumlah senyawa yang terekstrak ke dalam pelarut sudah berkurang, sehingga total tanin yang dihasilkan menurun. Penelitian tentang daun beluntas juga dilakukan oleh Septiana et al., (2014) yang melaporkan total tanin ekstrak daun beluntas sebesar 3,12\% menggunakan pelarut aquades $(1: 10 \mathrm{~b} / \mathrm{v})$ dengan metode maserasi.

\section{Aktivitas Antioksidan}

Semakin tinggi konsentrasi etanol dan semakin besar perbandingan bahan dengan etanol, maka nilai aktivitas antioksidan akan semakin meningkat, namun setelah mencapai titik optimum pada konsentrasi etanol $61,86 \%$ dan perbandingan bahan dengan etanol 1:10,14, nilai aktivitas antioksidan menurun dengan peningkatan konsentrasi etanol dan perbandingan bahan dengan etanol.

Hal ini disebabkan karena nilai aktivitas antioksidan dipengaruhi oleh jumlah komponen bioaktif yang memiliki fungsi sebagai antioksidan, seperti senyawa flavonoid dan tanin, dimana nilai aktivitas antioksidan meningkat sesuai dengan meningkatnya total flavonoid dan total tanin, namun setelah mencapai titik optimum, nilai aktivitas antioksidan menurun sesuai dengan menurunnya total flavonoid dan total tanin, sehingga dapat dikatakan bahwa terdapat korelasi positif antara total flavonoid dan total tanin yang terkandung pada ekstrak 
daun beluntas dengan nilai aktivitas antioksidan. Pernyataan tersebut diperkuat oleh penelitian Pujimulyani et al., (2010) yang melaporkan adanya korelasi positif antara total flavonoid dan total tanin pada ekstrak kunir putih dengan nilai aktivitas antioksidan. Penelitian tentang daun beluntas juga dilakukan oleh Widyawati et al., (2011) yang melaporkan aktivitas antioksidan ekstrak daun beluntas berada pada kisaran 80\%-90\% menggunakan pelarut metanol $(1: 15 \mathrm{~b} / \mathrm{v})$ dengan metode sokletasi.

\section{$\mathrm{IC}_{50}$}

Semakin tinggi konsentrasi etanol dan semakin besar perbandingan bahan dengan etanol, maka nilai $\mathrm{IC}_{50}$ akan semakin menurun, namun setelah mencapai titik optimum pada konsentrasi etanol 63,28\% dan perbandingan bahan dengan etanol 1:10,03, nilai $\mathrm{IC}_{50}$ meningkat dengan peningkatan konsentrasi etanol dan perbandingan bahan dengan etanol.

Hal ini disebabkan karena nilai $\mathrm{IC}_{50}$ dipengaruhi oleh nilai aktivitas antioksidan, dimana nilai $\mathrm{IC}_{50}$ menurun sesuai dengan meningkatnya nilai aktivitas antioksidan, namun setelah mencapai titik optimum, nilai $\mathrm{IC}_{50}$ meningkat sesuai dengan menurunnya nilai aktivitas antioksidan. Nilai $\mathrm{IC}_{50}$ yang rendah menunjukkan aktivitas antioksidan yang tinggi, sedangkan nilai $\mathrm{IC}_{50}$ yang tinggi menunjukkan aktivitas antioksidan yang rendah. Pernyataan tersebut diperkuat oleh penelitian Husni et al., (2014) yang melaporkan bahwa semakin rendah nilai $\mathrm{IC}_{50}$, maka semakin tinggi akitivitas antioksidannya.

Molyneux (2004) melaporkan bahwa suatu senyawa dikatakan memiliki aktivitas antioksidan yang sangat kuat jika nilai $\mathrm{IC}_{50}$ kurang dari 50 ppm. Oleh karena itu, ekstrak daun beluntas dalam penelitian ini memiliki aktivitas antioksidan yang tergolong sangat kuat. Penelitian tentang daun beluntas juga dilakukan oleh Widyawati et al., (2011) yang melaporkan $\mathrm{IC}_{50}$ ekstrak daun beluntas sebesar $3,71 \mathrm{mg} / \mathrm{L}$ menggunakan pelarut metanol $(1: 15 \mathrm{~b} / \mathrm{v})$ dengan metode sokletasi.

\section{Validasi Kondisi Optimum}

Berdasarkan hasil running software Minitab 17 diperoleh satu kondisi optimum, yaitu pada konsentrasi etanol $62,71 \%$ dan perbandingan bahan dengan etanol 1:10,14 yang diperkirakan akan menghasilkan nilai rendemen ekstrak sebesar $17,47 \%$ berat kering ekstrak, total flavonoid sebesar 46,28 mg QE/g berat kering ekstrak, total tanin sebesar 8,34 mg TAE/g berat kering ekstrak, aktivitas antioksidan sebesar $67,90 \%$, dan $\mathrm{IC}_{50}$ sebesar 3,73 ppm. Perbandingan nilai respon prediksi dengan nilai respon sebenarnya pada kondisi optimum dapat dilihat pada Tabel 6 . 
Tabel 6. Nilai respon prediksi dan nilai respon sebenarnya pada kondisi optimum

\begin{tabular}{|c|c|c|c|c|}
\hline Respon & Nilai Prediksi & $\begin{array}{c}\text { Nilai Sebenarnya } \\
\text { (Rata-rata) }\end{array}$ & $\begin{array}{c}\text { Standar } \\
\text { Deviasi }\end{array}$ & $\begin{array}{c}\text { Coefficient of } \\
\text { Variation (\%) }\end{array}$ \\
\hline $\begin{array}{c}\text { Rendemen Ekstrak (\% berat } \\
\text { kering ekstrak) }\end{array}$ & 17,47 & 18,20 & 0,459 & 2,52 \\
\hline $\begin{array}{c}\text { Total Flavonoid (mg QE/g } \\
\text { berat kering ekstrak) }\end{array}$ & 46,28 & 47,05 & 0,772 & 1,64 \\
\hline $\begin{array}{c}\text { Total Tanin (mg TAE/g berat } \\
\text { kering ekstrak) }\end{array}$ & 8,34 & 9,11 & 0,1834 & 2,01 \\
\hline Aktivitas Antioksidan (\%) & 67,90 & 65,80 & 0,720 & 1,09 \\
\hline IC50 (ppm) & 3,73 & 3,87 & 0,0396 & 1,02 \\
\hline
\end{tabular}

Validasi kondisi optimum dilakukan dengan melihat nilai coefficient of variation (CV) pada Tabel 6 dari masing-masing respon. Nilai CV rendemen ekstrak, total flavonoid, total tanin, aktivitas antioksidan, dan $\mathrm{IC}_{50}$ yang diperoleh relatif kecil. Hal ini membuktikan bahwa kondisi optimum pada masing-masing respon dapat diterima. Pernyataan tersebut diperkuat oleh penelitian Gomez and Gomez (1984) yang melaporkan bahwa kondisi optimum pada suatu respon dapat diterima apabila nilai $\mathrm{CV}$ kurang dari $15 \%$ untuk berbagai percobaan.

\section{KESIMPULAN DAN SARAN}

\section{Kesimpulan}

Konsentrasi etanol $62,71 \%$ dan perbandingan bahan dengan etanol 1:10,14 merupakan perlakuan optimum untuk menghasilkan ekstrak daun beluntas yang memiliki aktivitas antioksidan tertinggi yaitu sebesar $65,80 \%$, dengan $\mathrm{IC}_{50}$, rendemen ekstrak, total flavonoid, dan total tanin berturut-turut sebesar: $3,87 \mathrm{ppm}$, $18,20 \%$ berat kering ekstrak, 47,05 mg QE/g berat kering ekstrak, dan 9,11 mg TAE/g berat kering ekstrak.
Saran

Berdasarkan hasil penelitian ini disarankan untuk menggunakan konsentrasi etanol $62,71 \%$ dan perbandingan bahan dengan etanol 1:10,14 saat melakukan ekstraksi daun beluntas menggunakan metode microwave assisted extraction.

\section{DAFTAR PUSTAKA}

Alara, O.R., N.H. Abdurahman, and O.A. Olalere. 2018. Ethanolic extraction of bioactive compounds from Vernonia amygdalina leaf using response surface methodology as an optimization tool. Journal of Food Measurement and Characterization. 12:1107-1122.

Association of Official Analytical Chemists (AOAC). 1990. Official Method of Analysis of Association Official Agriculture Chemist. Association of Official Analytical Chemists, Inc, Washington D.C.

Box, G.E.P., J.S. Hunter, and W.G. Hunter. 1978. Statistics for Experimenters: Design, Innovation, and Discovery. 2nd Edition. John Wiley \& Sons, Inc, New York.

Dalimartha, S. 1999. Atlas Tumbuhan Obat Indonesia. Jilid I. Trubus Agriwidya, Jakarta.

Gomez, K.A. and A.A. Gomez. 1984. Statistical Procedures For Agricultural Research. 2nd Edition. John Wiley \& Sons, Inc, New York.

Handayani, H., F.H. Sriherfyna, dan Yunianta. 2016. Ekstraksi antioksidan daun sirsak metode ultrasonic bath (kajian rasio bahan:pelarut dan lama ekstraksi). Jurnal 
Pangan dan Agroindustri. 4(1):262-272.

Hassig, A., W.X. Linag, H. Schwabl, and K. Stampfli. 1999. Flavonoids and tannins: plant-based antioxidants with vitamin character. Medical Hypotheses. 52(5):479-481.

Husni, A., D.R. Putra, dan I.Y.B. Lelana. 2014. Aktivitas antioksidan Padina sp. pada berbagai suhu dan lama pengeringan. Jurnal Pascapanen dan Bioteknologi Kelautan dan Perikanan. $9(2): 165-173$.

Iriawan, N. dan Astuti, S.P. 2006. Mengolah Data Statistik dengan Mudah Menggunakan Minitab 14. Penerbit Andi, Yogyakarta.

Jain, T., V. Jain, R. Pandey, A. Vyas, and S.S. Shukla. 2009. Microwave assisted extraction for phytoconstituents-an overview. Asian Journal Research Chemistry. 1(2):19-25.

Jayanudin, A.Z. Lestari, dan F. Nurbayanti. 2014. Pengaruh suhu dan rasio pelarut ekstraksi terhadap rendemen dan viskositas natrium alginat dari rumput laut cokelat (Sargassum sp). Jurnal Integrasi Proses. 5(1):51-55.

Khan, R.A., M.R. Khan, S. Sahreen, and M. Ahmed. 2012. Evaluation of phenolic contents and antioxidant activity of various solvent extracts of Sonchus asper (L.) Hill. Chemistry Central Journal. 6:17.

Lestari, P., S. Wijana, dan W.I. Putri. 2014. Ekstraksi Tanin dari Daun Alpukat (Persea Americana Mill.) sebagai Pewarna Alami (Kajian Proporsi Pelarut dan Waktu Ekstraksi). Tesis S2. Tidak dipublikasikan. Program Pascasarjana Universitas Brawijaya, Malang.

McCabe, W.L., J.C. Smith, and P.H. Fred. 1993. Unit Operations of Chemical Engineering. 5th Edition. McGraw-HiII, Inc, New York.

Molyneux, P. 2004. The use of the stable free radical diphenylpicrylhydrazyl (dpph) for estimating antioxidant activity. Journal of Science and Technology. 26:211-219.

Montgomery, D.C. 2001. Design and Analysis of Experiments. 5th Edition. John Wiley $\&$ Sons, Inc, New York.

Pujimulyani, D., S. Raharjo, Y. Marsono, dan U. Santoso. 2010. Aktivitas antioksidan dan kadar senyawa fenolik pada kunir putih (Curcuma mangga Val.) segar dan setelah blanching. AGRITECH. 30(2):68-74.

Quan, P.T., T.V. Hang, N.H. Ha, N.X. De, and T.N. Tuyen. 2006. Microwave-assisted extraction of polyphenols from fresh tea shoot. Science and Technology Development Journal. 9(8):69-75.

Radojkovic, M., Z. Zekovic, S. Jokic, and S. Vidovic. 2012a. Determination of optimal extraction parameters of mulberry leaves using response surface methodology (rsm). Romanian Biotechnological Letters. 17(3):72977310.

Radojkovic, M., Z. Zekovic, S. Jokic, S. Vidovic, Z. Lepojevic, and S. Milosevic. 2012b. Optimization of solid-liquid extraction of antioxidants from black mulberry leaves by response surface methodology. Food Technology and Biotechnology. 50(2):167-176.

Rajan, S., S. Mahalakshmi, V.M. Deepa, K. Sathya, S. Shajitha, and T. Thirunalasundari. 2011. Antioxidant potentials of Punica granatum fruit rind extracts. International Journal of Pharmacy and Pharmaceutical Sciences. 3:82-88.

Septiana, A., Indrawati, dan Rustin. 2014. Analisis kadar alkaloid dan tanin tumbuhan beluntas (Pluchea indica Less.) pada lahan salin di desa asingi kecamatan tinanggea dan non salin di desa lambodijaya kecamatan lalembuu sulawesi tenggara. Jurnal Penelitian Biologi. 1(2):82-89.

Srimoon, R. 2018. The effect of Indian marsh fleabane (Pluchea indica (L.) Less) dried leaves extract against oxidative stress induced by hydrogen peroxide in Saccharomyces cerevisiae. Asia-Pacific Journal of Science and Technology. 23(3):1-7.

Suryani, N.C., D.G.M. Permana, dan A.A.G.N.A. Jambe. 2016. Pengaruh jenis pelarut terhadap kandungan total flavonoid dan aktivitas antioksidan ekstrak daun matoa (Pometia pinnata). Jurnal Ilmu dan Teknologi Pangan. 5(1):1-10.

Tan, M.C., C.P. Tan, and H.C. Wai. 2013. Effects of extraction solvent system, time and temperature on total phenolic content of henna (Lawsonia inermis) stems. International Food Research Journal. 
20:3117-3123.

Widyawati, P.S., C.H. Wijaya, dan P.S. Hardjosworo. 2011. Evaluasi aktivitas antioksidatif ekstrak daun beluntas (Pluchea indica) berdasarkan perbedaan ruas daun. Jurnal Teknologi Pangan. $5(1): 1-14$.

Yulianto, D. dan S.R. Savitri. 2019. Perbandingan kadar flavonoid total ekstrak etanolik daun beluntas (Pluchea indica $\mathrm{L}$.) berdasarkan variasi konsentrasi pelarut secara spektrofotometer uv-vis. Jurnal Ilmiah Ilmu Keperawatan dan Ilmu Kesehatan Masyarakat. 14(1):18-25. 